


\title{
ISOTERM ADSORPSI FENOL OLEH LEMPUNG ALAM
}

\author{
Nelly Wahyuni ${ }^{1 *}$, Imelda H. Silalahi ${ }^{1}$, Dina Angelina ${ }^{2}$ \\ ${ }^{1}$ Jurusan Kimia FMIPA, Universitas Tanjungpura \\ ${ }^{2}$ Dinas Lingkungan Hidup Kota Pontianak
}

*E-mail : nellywahyuni@chemistry.untan.ac.id

\begin{abstract}
Phenol is a pollutant that is very dangerous in the environment because it is toxic and difficult to degrade by decomposing organisms. Natural clay from Capkala District, Bengkayang Regency will be studied as phenol adsorbent. Batch experiments were carried out by varying the parameters like contact time of adsorption and initial phenol concentration. The equilibrium data were tested with Langmuir and Freundlich isotherm. The results showed that the optimum contact time for adsorption was 4 hours. The process of adsorption of phenol by natural clay follows the Langmuir adsorption isotherm model with an adsorption capacity of $0.65 \mathrm{mg} / \mathrm{g}$.
\end{abstract}

Keywords: adsorption isotherm, Freundlich, natural clay, phenol, Langmuir.

\begin{abstract}
Abstrak
Fenol merupakan polutan yang sangat berbahaya di lingkungan karena bersifat racun dan sulit terdegradasi oleh organisme pengurai. Lempung alam yang berasal dari Kecamatan Capkala, Kabupaten Bengkayang akan dikaji penggunaannya sebagai adsorben fenol. Adsorpsi dilakukan dengan metoda batch pada variasi waktu kontak adsorpsi dan konsentrasi awal fenol. Data kesetimbangan adsorpsi diuji dengan isoterm Langmuir dan Freundlich. Hasil penelitian menunjukkan waktu kontak optimum adsorpsi adalah 4 jam. Proses adsorpsi fenol oleh lempung alam mengikuti model isoterm adsorpsi Langmuir dengan kapasitas adsorpsi sebesar 0,65 mg/g.
\end{abstract}

Kata Kunci: fenol, Freundlich, isoterm adsorpsi, Langmuir, lempung alam 


\section{PENDAHULUAN}

Seiring dengan meningkatnya populasi penduduk dan perkembangan tekonologi, pencemaran air merupakan salah satu masalah serius yang dihadapi dan menjadi perhatian banyak pihak. Salah satu polutan yang berbahaya di lingkungan adalah fenol. Limbah fenol dapat berasal dari proses produksi pada berbagai industri seperi peleburan logam, plastik, polimer, farmasi, cat, pengolahan kayu (kayu lapis), pestisida organik, pulp dan kertas (Bismo, dkk., 2008., Afsharnia et al., 2016).

Fenol dan senyawa turunannya bersifat racun dan sangat sulit didegradasi oleh organisme pengurai. Air yang telah tercemar oleh fenol bagi manusia dapat menyebabkan degenerasi protein dan berbahaya bagi jantung, hati dan ginjal (Hudori dan Yulianto, 2011). Selain itu, senyawa fenol (gambar 1) bersifat korosif, dapat menyebabkan iritasi jaringan, kulit, mata dan mengganggu pernapasan manusia. Kadar maksimum senyawa fenol di limbah cair industri berkisar $0,2 \mathrm{mg} / \mathrm{L}-5,0 \mathrm{mg} / \mathrm{L}$ tergantung pada jenis industrinya (Slamet dkk., 2005). Ketentuan ini mengacu pada Keputusan Menteri Negera Lingkungan Hidup No 51 tahun 1995 tentang baku mutu limbah cair pada kegiatan industri. Oleh karena itu perlu dilakukan pencegahan terhadap semakin meluasnya pencemaran fenol, salah satunya melalui proses adsorpsi.<smiles>Oc1ccccc1</smiles>

Gambar 1. Struktur fenol Sumber: Anku et al., (2017)

Adsorpsi memiliki beberapa kelebihan jika dibandingkan dengan metode lainnya, diantaranya prosesnya relatif sederhana, efektivitas dan efisiensinya relatif tinggi dan adsorbennya dapat dipergunakan kembali (regenerasi). Bohli et al., (2013) menggunakan karbon aktif untuk menurunkan kadar fenol dari larutan. Angraini dkk., (2015) menggabungkan 2 jenis adsorben yaitu karbon aktif dan zeolit alam untuk menurunkan kadar fenol dengan metoda kolom.

Salah satu jenis adsorben yang potensial dimanfaatkan dalam adsorpsi fenol adalah lempung alam. Kalimantan Barat memiliki banyak endapan bahan galian baik endapan bahan galian logam maupun bahan galian nonlogam. Keberadaan bahan galian logam tersebut tersebar di beberapa kabupaten, salah satunya Kabupaten Bengkayang (khususnya Kecamatan Capkala). Penyusun utama lempung alam ini adalah kaolinit (Wahyuni et al., 2018).

Golongan kaolinit dipandang dari segi mineralogi struktur kisinya tersusun atas lapisan (sheet) tunggal $\mathrm{Al}_{2} \mathrm{O}_{3}$ dan $\mathrm{SiO}_{2}$. Struktur kaolinit ditampilkan pada gambar 2. 


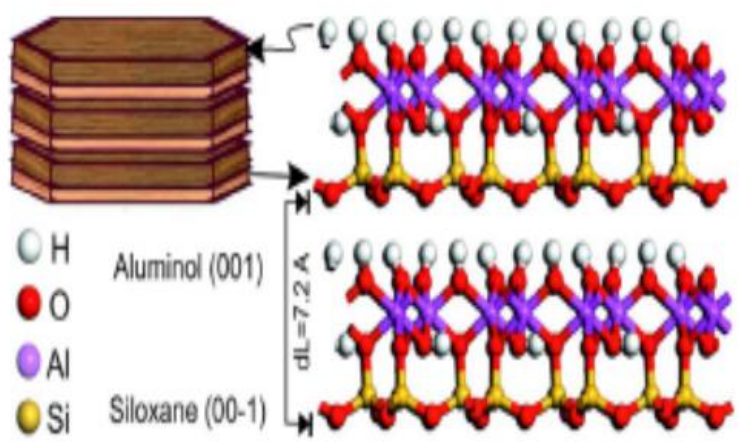

Gambar 2. Struktur kaolinit berdasarkan hasil simulasi molekul

Sumber: Awad et al., (2017)

Persamaan Freundlich dan Langmuir umumnya digunakan dalam pengolahan data adsorpsi dari larutan (Nethaji et al., 2013). Isoterm Freundlich merupakan persamaan yang menyatakan hubungan antara jumlah zat yang teradsorpsi dengan konsentrasi zat dalam larutan, dinyatakan dalam persamaan berikut (Oscik, 1983):

$$
\begin{aligned}
& \mathrm{m}=\mathrm{kC}(1 / \mathrm{n}) \\
& \log \mathrm{m}=\log \mathrm{k}+1 / \mathrm{n} \log \mathrm{C}
\end{aligned}
$$

dimana,

m: jumlah gram teradsorpsi/gram adsorben

$\mathrm{C}$ : konsentrasi adsorbat pada kesetimbangan

$\mathrm{n}$ dan k: konstanta

Dengan mengukur $\mathrm{m}$ sebagai fungsi $\mathrm{C}$ maka nilai $\mathrm{n}$ dan $\mathrm{k}$ dapat ditentukan dari harga slop dan intersepnya. Isoterm Freundlich tidak berlaku jika konsentrasi (atau tekanan) dari zat yang akan teradsorpsi terlalu tinggi. Kelemahan persamaan ini tidak dapat menduga nilai jerapan maksimum (adsorption maximum). Nilai $1 / \mathrm{n}$ dan $\mathrm{k}$ sering digunakan untuk membuat kesimpulan tentang mekanisme jerapan. Nilai $\mathrm{n}$ menyatakan besarnya afinitas adsorben terhadap adsorbat. Makin besar afinitas adsorben terhadap adsorbat, maka semakin besar kapasitas adsorben menyerap adsorbat dan sebaliknya.

Isoterm Langmuir menunjukan bahwa pada permukaan adsorben terdapat sejumlah tertentu situs aktif yang sebanding dengan luas permukaan. Pada setiap situs aktifnya hanya ada satu molekul yang dapat diadsorpsi. Ikatan antara zat teradsorpsi dengan adsorben terjadi secara fisika atau kimia. Isoterm adsorpsi Langmuir dinyatakan dalam persamaan 3 (Yang, 2003):

$$
\mathrm{m}=\frac{b+K C}{(1+K C)}
$$

Persamaan linear dari persamaan Langmuir dapat dinyatakan dalam persamaan 4 berikut ini: 


$$
\frac{C}{m}=\frac{1}{b K}+\frac{C}{b}
$$

dimana:

$\mathrm{m}$ : jumlah gram teradsorpsi per gram adsorben pada konsentrasi $\mathrm{C}$

$\mathrm{K}$ : konstanta kesetimbangan (afinitas adsorpsi)

$\mathrm{C}$ : konsentrasi ion yang teradsorpsi saat keadaan jenuh

b: kapasitas adsorpsi maksimum

dengan memplot $\mathrm{C} / \mathrm{m}$ terhadap $\mathrm{C}$ akan diperoleh garis lurus sehingga konstanta kesetimbangan $\mathrm{K}$ dan kapasitas adsorpsi maksimum $\mathrm{b}$ dapat ditentukan dari harga slop dan intersep.

\section{METODE PENELITIAN}

Bahan dan Peralatan. Pada penelitian ini digunakan bahan kimia seperti aminoantipirin $2 \%$, fenol, $\mathrm{K}_{3} \mathrm{Fe}(\mathrm{CN})_{3}$, Buffer $\mathrm{pH}=10$. Lempung alam berasal dari Kecamatan Capkala, Kabupaten Bengkayang. Sedangkan alat-alat utama yang digunakan adalah Gas Sorption Analyzer (GSA) NOVA 1000 dan spektrofotometer UV-Vis tipe Genesys.

\section{Metode Penelitian}

1. Preparasi Lempung alam

Lempung dari Desa Capkala Kabupaten Bengkayang dipanaskan pada temperatur $80^{\circ} \mathrm{C}$ selama 5 jam, dihaluskan dan dilakukan pengayakan dengan ayakan 80 mesh. Setelah itu dicuci dengan akuades sebanyak 3 kali dan dilakukan penyaringan. Lempung basah selanjutnya dikeringkan pada temperatur $80^{\circ} \mathrm{C}$ selama 24 jam, kemudian diayak lagi dan siap digunakan sebagai adsorben (Wahyuni dkk., 2008). Lempung alam yang digunakan memiliki luas permukaan spesifik, rerata jejari pori dan volume total pori berturut-turut $6,305 \mathrm{~m}^{2} / \mathrm{g}, 26,974 \AA$, dan $0,0085 \mathrm{cc} / \mathrm{g}$.

2. Penentuan waktu optimum adsorpsi fenol oleh lempung alam

Sebanyak 0,5 g lempung alam diinteraksikan dengan $20 \mathrm{~mL}$ larutan fenol 40mg/L, kemudian diaduk dengan shaker kecepatan $200 \mathrm{rpm}$. Waktu pengocokan divariasi yaitu 1, 2, 3, 4, 5, 6 dan 12 jam. Setelah itu, suspensi analit yang telah diinteraksikan dengan adsorben dipisahkan dengan cara penyaringan. Konsentrasi fenol pada supernatan ditentukan berdasarkan pengukuran absorbansi pada panjang gelombang $505 \mathrm{~nm}$ menggunakan spektrofotometer UV-vis. Waktu optimum adsorpsi fenol ditentukan berdasarkan metode statistik.

3. Penentuan kapasitas adsorpsi lempung alam terhadap fenol

Sebanyak $0,5 \mathrm{~g}$ lempung alam dimasukkan dalam botol yang berisi masingmasing $20 \mathrm{~mL}$ larutan fenol dengan variasi konsentrasi 30mg/L, $35 \mathrm{mg} / \mathrm{L}, 40 \mathrm{mg} / \mathrm{L}$ dan $45 \mathrm{mg} / \mathrm{L}$, kemudian diaduk dengan shaker kecepatan $200 \mathrm{rpm}$ pada waktu optimum. Selanjutnya, suspensi analit yang telah diinteraksikan dengan adsorben dipisahkan dengan cara penyaringan dan diukur absorbansinya. Kapasitas adsorpsi ditentukan melalui persamaan isoterm adsorpsi. 


\section{Penentuan kadar fenol (SNI 06-6989.21, 2004)}

Pewarnaan fenol terlarut dilakukan dengan cara mencampurkan $0,5 \mathrm{~mL}$ sampel larutan dengan pereaksi pewarna $0,05 \mathrm{~mL} 4$-aminoantipirin $2 \%(\mathrm{~b} / \mathrm{v}), 0,05 \mathrm{~mL}$ kalium heksasiano ferrat (III) $8 \%(\mathrm{~b} / \mathrm{v}), 0,5 \mathrm{~mL}$ buffer $\mathrm{pH} 10$, dan 1,5 mL akuades. Pengukuran dilakukan pada panjang gelombang $505 \mathrm{~nm}$ menggunakan spektrofotometer UV-Vis. Konsentrasi fenol dihitung menggunakan kurva standar dengan rumus korelasi konsentrasi fenol $(\mathrm{x})$ dan absorbansi $(\mathrm{y})$ yaitu $\mathrm{y}=0,0541 \mathrm{x}-$ 0,012 dengan koofesien korelasi $\mathbf{R}^{2}=0,9895$.

\section{HASIL DAN PEMBAHASAN}

\section{Penentuan Waktu Kontak Kesetimbangan Adsorpsi Fenol}

Waktu kontak antara adsorben dengan adsorbat merupakan salah satu faktor yang mempengaruhi kemampuan adsorpsi suatu adsorben. Waktu kontak adsorpsi fenol dengan adsorben lempung berhubungan dengan berapa lama waktu yang diperlukan agar fenol mampu diadsorpsi secara optimal oleh lempung. Studi adsorpsi fenol oleh lempung alam diawali dengan penentuan waktu kesetimbangan optimum. Semua data perhitungan konsentrasi fenol hasil adsorpsi diperoleh dari hasil analisis dengan menggunakan spektrofotometer UV-Vis pada panjang gelombang $505 \mathrm{~nm}$ (panjang gelombang maksimum fenol) setelah dilakukan pewarnaan.

Waktu kontak mempengaruhi mempengaruhi konsentrasi fenol yang teradsorpsi oleh lempung alam (tabel 1). Konsentrasi fenol yang teradsorpsi meningkat seiring dengan meningkatnya waktu kontak adsorpsi. Peningkatan ini berlangsung hingga waktu kontak 4 jam kemudian menurun pada waktu kontak 5 jam dan meningkat kembali pada waktu kontak 6 dan 12 jam dimana adsorpsi memperlihatkan kecenderungan yang relatif konstan.

Berdasarkan uji statistik (Uji t) kondisi kesetimbangan antara molekul fenol dengan permukaan adsorben lempung diperoleh pada waktu kontak 4 jam, dimana pada waktu ini adsorpsi fenol oleh adsorben adalah optimum. Hasil riset ini juga menunjukkan bahwa lempung alam yang digunakan pada penelitian ini memerlukan waktu kontak yang lebih cepat dibanding lempung alam monmorrilonit (Mustapha et al., 2012).

Tabel 1. Pengaruh waktu kontak terhadap adsorpsi fenol oleh lempung alam

\begin{tabular}{|c|c|c|c|}
\hline $\begin{array}{c}\text { Waktu } \\
\text { kontak } \\
(\text { jam })\end{array}$ & $\begin{array}{c}\text { [Fenol] awal (Co) } \\
(\mathrm{mg} / \mathrm{L})\end{array}$ & $\begin{array}{c}\text { [Fenol] setimbang }(\mathrm{Ca}) \\
(\mathrm{mg} / \mathrm{L})\end{array}$ & $\begin{array}{c}\text { [Fenol] teradsorpsi }(\mathrm{Cx}) \\
(\mathrm{mg} / \mathrm{L})\end{array}$ \\
\hline 1 & 40,70 & 29,24 & 11,45 \\
\hline 2 & 40,70 & 28,21 & 12,49 \\
\hline 3 & 40,70 & 25,01 & 15,69 \\
\hline 4 & 40,70 & 19,06 & 21,63 \\
\hline 5 & 40,70 & 23,42 & 17,27 \\
\hline 6 & 40,70 & 20,55 & 20,14 \\
\hline 12 & 40,70 & 19,34 & 21,35 \\
\hline
\end{tabular}




\section{Kapasitas Adsorpsi Lempung Alam Terhadap Fenol}

Untuk mengetahui karakteristik adsorpsi dari sisi termodinamika, maka dalam penelitian ini dilakukan adsorpsi isotermal fenol dengan variasi konsentrasi awal fenol. Dalam penelitian ini, adsorpsi fenol dilakukan pada kondisi optimum adsorpsi fenol oleh lempung alam. Nilai konsentrasi awal adsorbat berbanding lurus dengan konsentrasi adsorbat yang teradsorpsi pada setiap adsorben (tabel 2). Kurva isoterm adsorpsi diperoleh dengan memplot konsentrasi setimbang fenol (Ca) terhadap kapasitas $\operatorname{adsorpsi}(\mathrm{m})$.

Tabel 2. Adsorpsi fenol pada variasi konsentrasi

\begin{tabular}{|c|c|c|}
\hline $\begin{array}{c}\text { [fenol] awal } \\
(\mathrm{Co})(\mathrm{mg} / \mathrm{L})\end{array}$ & $\begin{array}{c}\text { [fenol] setimbang }(\mathrm{Ca}) \\
(\mathrm{mg} / \mathrm{L})\end{array}$ & $\begin{array}{c}\text { [fenol] teradsorpsi } \\
(\mathrm{Cx})(\mathrm{mg} / \mathrm{L})\end{array}$ \\
\hline 30,03 & 16,80 & 13,22 \\
\hline 35,28 & 20,68 & 14,59 \\
\hline 40,07 & 25,42 & 14,64 \\
\hline 45,74 & 31,15 & 14,59 \\
\hline
\end{tabular}

Isoterm lempung alam membentuk kurva "L" yang mana merupakan salah satu ciri isoterm Langmuir (gambar 2). Kurva ini menunjukan suatu proses adsorpsi yang terbatas sampai konsentrasi tertentu dan membentuk lapisan tunggal pada permukaan adsorben. Isoterm adsorpsi ini berlaku pada antar muka cairan dan padatan. Adsorpsi dapat terjadi karena adanya ikatan antara situs aktif dari adsorben dengan adsorbat sehingga membentuk lapisan penyerapan tunggal (monolayer adsorption) pada permukaan adsorben (Oscik, 1983).

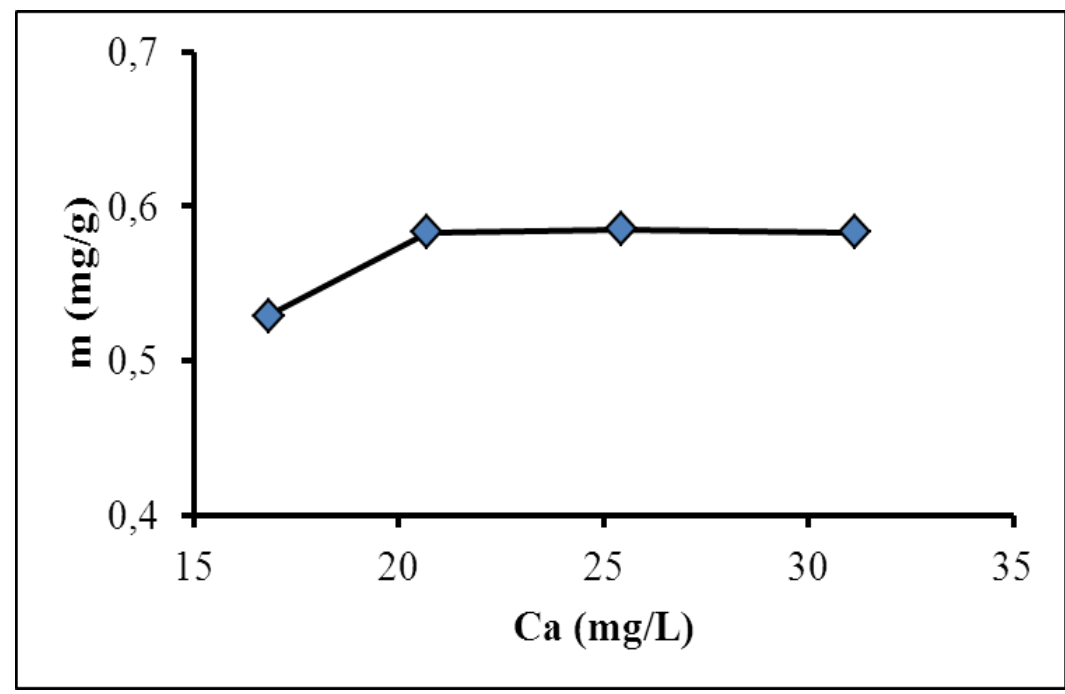

Gambar 2. Kurva isoterm adsorpsi fenol oleh lempung alam

Penerapan model isoterm adsorpsi Freundlich dan Langmuir untuk mengolah data yang diperoleh dari penelitian dapat diperoleh nilai parameter termodinamika isoterm adsorpsi. Model adsorpsi pada adsorben lempung alam cenderung mengikuti isoterm adsorpsi Langmuir (tabel 3). Hal ini ditandai dengan harga koefisien korelasi $\left(\mathrm{R}^{2}\right)$ persamaan Langmuir lebih mendekati nilai= 1 dibandingkan $\mathrm{R}^{2}$ untuk persamaan Freundlich. Adsorpsi fenol oleh lempung alam terjadi melalui pembentukan ikatan hidrogen antara situs aktif adsorben yaitu gugus silanol dari lempung alam dan gugus $\mathrm{OH}$ dari fenol (Mustapha et al., 2012). Situs aktif pada adsorben sebanding dengan luas 
permukaan (Amri dkk., 2004). Kapasitas adsorpsi lempung alam kaolinit sebesar 0,65 $\mathrm{mg} / \mathrm{g}$ lebih besar dari yang diperoleh Alkaram et al. (2009) yaitu 0,468 mg/g, namun lebih rendah bila dibandingkan dengan lempung monmorrilonit (Hamdaoui et al., 2018).

Tabel 3. Perbandingan persamaan garis, nilai b serta koefisien korelasi $\left(\mathrm{R}^{2}\right)$ dari persamaan isoterm Langmuir dan Freundlich

\begin{tabular}{|l|l|l|}
\hline Model Isoterm Adsorpsi & $\begin{array}{l}\text { Parameter } \\
\text { Adsorpsi }\end{array}$ & Nilai Hasil Perhitungan \\
\hline Langmuir & Persamaan garis & $y=1,5374 x+4,8675$ \\
\hline & $b(\mathrm{mg} / \mathrm{g})$ & 0,65 \\
\hline & $E(\mathrm{~kJ} / \mathrm{mol})$ & 5,03 \\
\hline & $R^{2}$ & 0,98 \\
\hline Freundlich & Persamaan garis & $y=0,1458 x-0,4227$ \\
\hline & $k(\mathrm{mg} / \mathrm{g})(\mathrm{L} / \mathrm{mg})^{n}$ & 0,30 \\
\hline & $n$ & 6,85 \\
\hline & $R^{2}$ & 0,60 \\
\hline
\end{tabular}

\section{PENUTUP}

Lempung alam yang berasal dari kecamatan Capkala, kabupaten Bengkayang berpotensi digunakan untuk menurunkan kandungan fenol di perairan atau limbah. Setiap gram lempung alam yang dikontakkan selama 4 jam dengan 1 liter larutan fenol mampu menyerap fenol sebanyak 0,65 ppm.

\section{DAFTAR PUSTAKA}

Afsharnia, M. Saeidi, M. Aarei, A. Narooie, M. R. Biglari, H. 2016. Phenol Removal from Aqueous Environment by Adsorption onto Pomegranate Peel Carbon. Electronic physician, 8(11), pp: 3248-3256.

Alkaram, U. F. Mukhlis, A. A. Al-Dujaili, A. H. 2009. The Removal of Phenol from Aqueous Solutions by Adsorption Using Surfactant-Modified Bentonite and Kaolinite. Journal of Hazardous Materials, 169(1-3), pp :324-32.

Angraini, R. Wahyuni, N. dan Gusrizal. 2015. Adsorpsi Fenol Oleh Kombinasi Adsorben Zeolit Alam Dan Karbon Aktif Dengan Metode Kolom. Jurnal Kimia Khatulistiwa, 4(1), pp: 29-34.

Anku, W.W. Mamo, M.A and Govender, P.P. (2017). Phenolic Compounds in Water: Sources, Reactivity Toxicity and Treatment Methods in Phenolic Compounds - Natural Sources, Importance and Applications. pp: 420-423, Intech publisher.

Amri, A. Supranto dan Fahrurozi, M. 2004. Kesetimbangan Adsorpsi Optional Campuran Biner $\mathrm{Cd}$ (II) dan $\mathrm{Cr}$ (III) dengan Zeolit Alam Terimpregnasi 2merkaptobenzotiazol, Jurnal Natur Indonesia, 6 (2), pp: 111-117. 
Awad, M. E. López-Galindo, A. Setti, M. El Rahmanya, M. M. Iborra, C. V. 2017. Kaolinite in pharmaceutics and biomedicine (Review). International Journal of Pharmaceutic. 533, pp: 34-48.

Bismo, S., Kustiningsih, I., Jayanudin, Haryanto, F., \& Saptono, H. J. (2008). Studi awal degradasi fenol dengan teknik ozonasi di dalam reaktor annular.

in Prosiding seminar nasional rekayasa kimia dan proses 2008. pp. J-081-1- J-081-8.

Bohli, T. Fiol, N. Villaescusa, I. and Ouederni, A. 2013. Adsorption on Activated Carbon from Olive Stones: Kinetics and Equilibrium of Phenol Removal from Aqueous Solution. Journal of Chemical Engineering \& Process Technology. pp: 4-6.

Hamdaoui, M. Hadri, M. Bencheqroun, Z. Draoui, K. Nawdali, M. Zaitan, H. Barhoun, A. 2018. Improvement of Phenol Removal from Aqueous Medium by Adsorption on Organically Functionalized Moroccan Stevensite. Journal of Materials and Environmental Sciences. 9(4), pp: 1119-1128.

Menteri Negara Lingkungan Hidup. (1995). Keputusan Menteri Negara Lingkungan Hidup, Nomor: KEP-51/MENLH/10/1995 Tentang Baku Mutu Limbah Cair Bagi Kegiatan Industri.

Hudori dan Yulianto, A. 2011. Penurunan Fenol Melalui Proses Adsorptive Micellar Flocculation. Jurnal Sains dan Teknologi Lingkungan. 3(1), pp: 066-072.

Mustapha, D. Fatiha, D. Bouchekara, M. Djafri, A. 2012. Adsorption of Phenol on Natural Clay. Applied and Water Science. 2, pp: 77-86.

Nethaji, S. Sivasamy, A. Mandal., A.B. 2013. Adsorption Isotherms, Kinetics and Mechanism for the Adsorption of Cationic and Anionic Dyes onto Carbonaceous Particles Prepared from Juglans regia Shell Biomass. International Journal of Environmental Science and Technology. 10, pp : 231-242.

Oscik, J. (1983) Adsorption, Ellis Horwood Ltd, Chicester, England.

Slamet, R. Arbianti, dan Daryanto. 2005. Pengolahan Limbah Organik (Fenol) dan Logam Berat $\left(\mathrm{Cr}^{6+}\right.$ Atau $\left.\mathrm{Pt}^{4+}\right)$ Secara Simultan dengan Fotokatalis $\mathrm{TiO}_{2}, \mathrm{ZnO}-\mathrm{TiO}_{2}$, dan Cds-TiO2, Makara Teknologi. 9(2), pp: 66-71.

Wahyuni, N. Silalahi, I. H. Arryanto, Y. Sutarno, dan Zupriadi, Y. 2008. Hidrolisis Lempung Dari Kecamatan Capakala Dengan Variasi Konsentrasi Larutan Asam klorida. Jurnal Zeolit Indonesia. 7(1), pp: 12-21.

Wahyuni, N., Zissis, G., \& Mouloungui, Z. (2018). Characterization of acid sites on modified kaolinite by FTIR. AIP Conf. Proc. 2026, 020042-1-020042-7, AIP publisher. Yang, R. T., (2003). Adsorbents: fundamentals and applications, John Wiley and Sons, Inc., USA.

Yang, R. T. (2003) Adsorbents: Fundamentals and Applications, John Wiley and Sons, Inc., USA. 